\title{
ホルモン型除草剤クロメプロップの 殺草作用発現機構の研究
}

\author{
春原由香里*
}

キーワード：ホルモン型除草㶡, クロメプロップ, オーキシン結合蛋白質, エチレン

Key Words: auxin-type herbicide, clomeprop, auxin-binding proteins, ethylene

クロメプロップ (2- (2, 4-dichloro-m-tolyoloxy) propionanilide)は, フェノキシ系の水稲用選択性除 草剤で,ノビエを除く一年生雑草およびマツバイ, ホ タルイ，ミズガヤツリ等の一部の多年生雑草を制御 する。本剤は感受性植物に対して，いわゆる，オー キシン斉と同様な症状を示すことが知られているが, 除草剤としての詳細な作用機構は明らかにされてい ない。

本剤は, 植物体中 (イネ) に吸収された後, 次の 主代謝経路で代謝されるものと推定されている ${ }^{2)}$ 。(1) クロメプロップのアミド結合部位の加水分解により 2-(2,4-dichloro- $m$-tolyloxy) propionic acid (DMPA) とアニリンが生成。(2) DMPA はフェニル 環メチル側鎖の水酸化を受けて3- $\mathrm{CH}_{2} \mathrm{OH}-\mathrm{DMPA}$ を 生成。(3)3- $\mathrm{CH}_{2} \mathrm{OH}-\mathrm{DMPA}$ は抱合化（グルコース） を受けて水溶性代謝物へと変化。(4)さらに一部は非 抽出性代謝物へと変化。また, その他にクロメプロ ップが直接水酸化された後, 加水分解する副経路の 存在も推定されている。上記(1)のように,クロメプ ロップは植物体内でアリルアシルアミダーゼを介し, アシルアミドの加水分解から生じた代謝物 DMPA と変化し, その結果, より強いオーキシン活性を有 すことが報告されている ${ }^{9,11)}$ 。また，上記(2)のように

\footnotetext{
* 千葉大学園芸学部

干271-8510 千葉県松戸市松戸648

Yukari Sunohara: Study of Mode of Action of Clomeprop.

Faculty of Horticulture, Chiba University, 648 Matsudo, Matsudo, Chiba 271-8510, Japan (2000年 5 月29日受理)
}

フェニル環の3-位におけるメチル基の位置が転移し たり，水酸化されることによって不活性化すること が知られている。そして, DMPA の体内保存量およ び3- $\mathrm{CH}_{2} \mathrm{OH}-\mathrm{DMPA}$ とそのグルコース抱合体になる 解毒代謝速度の差異により選択性が示されるとされ ている ${ }^{11)}$ 。実際,クロメプロップに抵抗性であるイネ では, 活性本体であると考えられている DMPA から 殺草活性のない化合物 (3- $\left.\mathrm{CH}_{2} \mathrm{OH}-\mathrm{DMPA}\right)$ への代 謝速度が早く，感受性広葉植物では，その変換速度 が遅いことが示されており ${ }^{10)}$, その解毒代謝速度の差 異により DMPA の体内濃度に差が生じることで, 選 択性が発現していると考えられる。さらに，ダイコ ン幼植物を用いた試験では，クロメプロップ処理後 のオーキシン活性は,クロメプロップ自身ではなく， DMPA の茎葉中存在量と高い相関関係があることが 示されている9。このことから,クロメプロップ自身 は活性を持たず,活性本体は DMPA である可能性が 示唆されている。しかし，クロメプロップ自身もオ 一キシン活性を示すのではないかとする報告もある。 本研究では，クロメプロップの作用機構解明に向 けての端諸として，まず，クロメプロップ自身のオ 一キシン活性の有無についての検討を行うこととし た。次に,クロメプロップあるいは DMPA の持つ多 様な生理作用のうち，いずれの作用が直接的に殺草 活性の発現に関与しているのかについて検討した。 オーキシンの主要な生理作用の 1 つに, 細胞壁の伸 長促進作用があるが，殺草活性への直接的な関与に ついては疑問視する声がある。また，その他の主要 な生理作用としては, 1-aminocyclopropane-1-carboxylate (ACC) synthase の誘導によるエチレン生 合成の促進がある。近年, この生理作用とホルモン 型除草剤の殺草活性との関与を示唆する報告がなさ れており，数種のホルモン型除草風に対して抵抗性 を持つ wild mustardのバイオタイプを用いた試験で は, 抵抗性, 感受性のバイオタイプ間で, 薬凧の吸 
収, 移行, 代謝には差が認められないものの, エチ レン生成量には大きな差があることが示されだ)。ま た，数種のホルモン型除草剤の生育抑制効果とエチ レン生成量との間には, 非常に高い正の相関関係が あることも報告されている ${ }^{1)}$ これらを踏まえ，本研 究ではクロメプロップの殺草作用発現機構を解明す ることを目的とし，特にクロメプロップ処理後のエ チレンの作用に焦点を当てて研究を行った。ここで は, 研究結果を以下のように要約する。なお, 紙面 の都合により, 研究内容の詳細については, 引用文 献を参照していただきたい。

\section{1. クロメプロップと DMPA のオーキシン活性 とオーキシン結合蛋白質 (ABP) への結合 ${ }^{4)}$}

上述のように，クロメプロップは植物体内で加水 分解され DMPA となり,より強いオーキシン活性を 示すとされている。しかしながら，クロメプロップ 自身がオーキシン活性を示すかについての十分な検 討はなされていない。そこで,クロメプロップ自身 のオーキシン作用の有無を検討するため, 数種のオ ーキシン活性試験や原形質膜上のオーキシン作用の

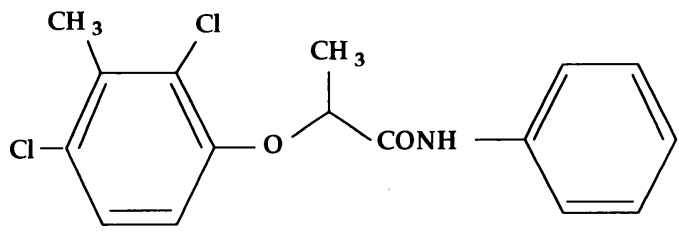

2-(2,4-dichloro- $m$-tolyloxy) propionanilide (clomeprop)

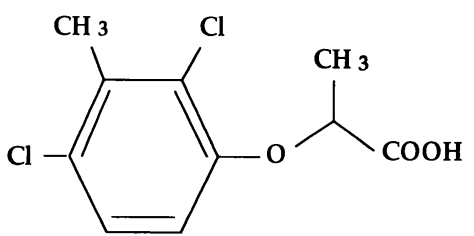

2-(2,4-dichloro- $m$-tolyloxy) propionic acid (DMPA)

Fig. 1. Chemical structures of clomeprop and DMPA
受容体と推定されているオーキシン結合蛋白質との 結合活性試験を行い, DMPA やオーキシン類との比 較を行った。

トウモロコシ (Zea mays L.cv. Honey Bantam), ヤエナリ (Phaseolus aureus) を供試植物として, 各 薬剤による生長阻害試験を行った結果, クロメプロ ップは DMPA, indole-3-acetic acid (IAA), 1naphthylacetic acid (NAA)よりも低い阻害活性を 示した。次に,オーキシン活性試験である, トウモ ロコシ子葉鞘伸長促進活性試験, ヤエナリ下胚軸届 曲試験, エチレン生成促進試験を行った結果, DMPA はIAA やNAA よりも活性がやや低いものの,クロ メプロップとの比較においては, いずれも高い活性 を示していた。また，クロメプロップはオーキシン 結合蛋白質に結合せず，つまりオーキシンとして認 識されなかったが, DMPA，IAA，NAA は認識さ れた (Fig. 2)。

このことは, クロメプロップ自身はオーキシン活 性を示さず，もしくは示しているとしても非常に弱 く,植物体内で DMPA に加水分解された後にオーキ シン結合蛋白質に主にオーキシンとして認識され,

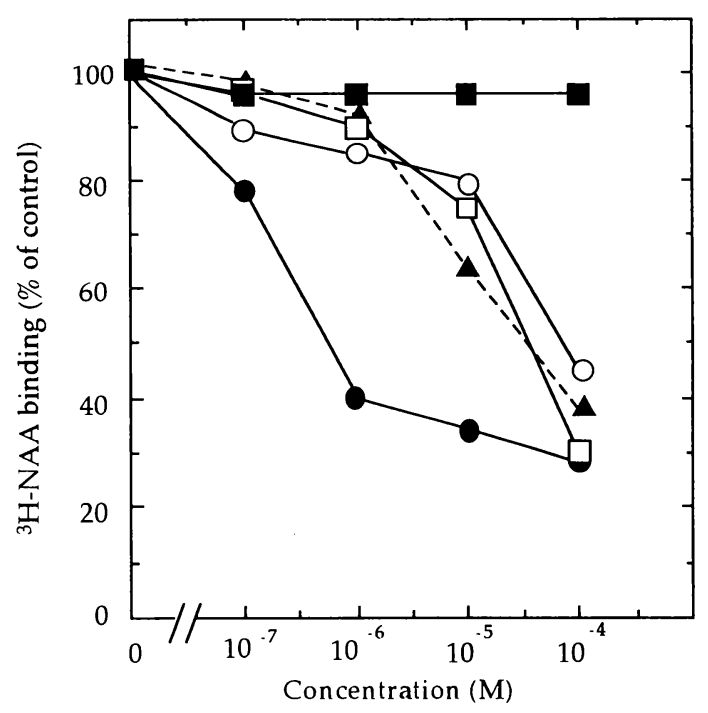

Fig. 2. Competition by clomeprop, DMPA, PCIB and auxins for ${ }^{3} \mathrm{H}-\mathrm{NAA}$ binding to maize auxinbinding proteins.

Symbol: $\square$; clomeprop, $\square$; DMPA, $\bigcirc$; IAA, ; NAA, $\boldsymbol{\Delta}$; PCIB 
Table 1. Effect of pretreated AOA on clomeprop- or DMPA-induced leaf angle change in radish seedlings.

\begin{tabular}{lcrr}
\multicolumn{1}{c}{ Treatment } & Hours after treatment & \multicolumn{2}{c}{ Leaf angle $\left(\alpha^{\circ}\right)$} \\
\cline { 3 - 4 } & & \multicolumn{1}{c}{ Cotyledon } & $10.1 \pm 2.2$ \\
\hline control & 24 & $60.3 \pm 3.6$ & $9.0 \pm 3.1$ \\
control+AOA & 24 & $59.3 \pm 4.2$ & $14.5 \pm 2.8$ \\
clomeprop & 24 & $82.5 \pm 4.5$ & $14.0 \pm 3.4$ \\
clomeprop+AOA & 24 & $65.5 \pm 5.2$ & $24.5 \pm 6.7$ \\
DMPA & 24 & $137.7 \pm 7.9$ & $21.0 \pm 4.6$ \\
DMPA+AOA & 24 & $106.0 \pm 12.9$ & $11.2 \pm 2.7$ \\
control & & & $10.5 \pm 2.8$ \\
control+AOA & 48 & $61.3 \pm 4.2$ & $37.3 \pm 7.6$ \\
clomeprop & 48 & $61.0 \pm 3.9$ & $30.9 \pm 10.4$ \\
clomeprop+AOA & 48 & $120.5 \pm 5.8$ & $50.9 \pm 10.5$ \\
DMPA & 48 & $93.2 \pm 5.3$ & $45.0 \pm 9.3$ \\
DMPA+AOA & 48 & $152.7 \pm 6.3$ & $121.0 \pm 10.1$ \\
\hline
\end{tabular}

The test compounds: Radish shoots were treated with clomeprop or DMPA.

The test compounds+AOA: Radish shoots were pretreated with AOA and then treated with clomeprop or DMPA.

オーキシン活性を示している可能性が高いことを示 唆している。

\section{2. クロメプロップ, DMPA 処理後の形態異常 へのエチレンの関与 ${ }^{5)}$}

クロメプロップ処理後に, 葉のカーリング, 葉柄 間角度の増大，伸長阻害といった形態異常が引き起 こされるが, それらの形態異常にエチレンが関与し ている可能性について検討し，次の結果を得た。

ダイコン (Raphanus sativus L. var. hortensis cv. Shogoin)幼植物にクロメプロップまたは DMPA を 茎葉処理すると, 上記のような形態異常 (葉のカー リングや葉柄間角度の増大, 伸長阻害) が現れたが, エチレン生成阻害剤である AOA (aminooxyacetic acid）を前処理することで,それらの形態異常は軽減 した(Table 1)。また，クロメプロップやDMPA 処 理後の上記の作用は, エチンン作用阻害剤である NBD （2,5-norbornadiene）を後処理することで, ほほ完 全に抑えられた。また，実際に，クロメプロップあ るいは DMPA を茎葉処理すると,エチレン生成量が 増大することが確認されたが, その増大は DMPA 処 理で,より早く引き起こされた。(Fig. 3A)。つまり, 両薬剤間には, エチレン生成開始時間にずれがある ことが示された。次に,クロメプロップ, DMPA 処 理後のエチレン生成の誘導メカニズムについての検 討を行った。クロメプロップまたは, DMPA 処理後
に ACC oxidase 活性は増大しなかったが, 両薬羭と もにエチレン生合成の律速䣲素である ACC synthase 活性は増大させた。また，その活性増大の開始時間 にも両楽剤間で，エチレン生成と同様なずれが確認 された。,ノーザンハイブリダイゼーションの結果, DMPA はオーキシン誘導型の $R s-S A U R$ 遺伝子を発 現していた。つまり，ダイコン中では，DMPA はオ ーキシンとして作用したいることが確認された。

このことより,クロメプロップは植物体内で DMPA へと変化し, DMPA がオーキシンとして作用するこ とで, ACC synthase の遺伝子発現を誘導させ, 結果 として ACC synthase 活性を増大させることで大量 のエチレン生成を引き起こしている可能性が高いも のと考えられた。そして，このように生成されたエ チレンが, ダイコンの形態的変化を引き起こしてい るものと推察された。

\section{3. 茎葉処理と根部処理での形態異常の程度差 の発現要因 ${ }^{6)}$}

クロメプロップや DMPA が引き起こす生育抑制効 果や形態異常の程度は茎葉処理後と根部処理後で大 きく異なることが知られている。ここでは, クロメ プロップ, DMPA の根部処理による形態異常へのエ チレンの関与について調查し,さらに上記 $2 . の$ 茎葉 処理での結果と比較することにより, エチレン生合 成系を軸とした両剤処理後の形態異常の差異の発現 
要因について検討した。

クロメプロップをダイコンに茎葉処理すると, 葉 のカーリングや葉柄間角度の増大が現れたが, 根部 処理した場合, それらの作用は非常にわずかであっ た。一方,ダイコンにDMPA を根部処理すると, 茎 葉処理よりも顕著な葉のカーリングや葉柄間角度の 増大が見られたが, それらは AOA やNBD を処理す ることで抑えられた。また,クロメプロップ根部処 理後のエチレン生成量は, 茎葉処理と比較すると非 常に少量であった (Fig. 3B)。そして, 茎葉処理の 場合には, クロメプロップと DMPA 間で, エチレン 生成の量的, 時間的な差がわずかであったのに対し, 根部処理ではその差が大きく, つまり, DMPA の方 がより早くエチレン生成を誘導し, その生成量も著 しく多かった。また, 両薬片間での処理部位による ACC synthase 活性の量的, 時間的な差は, エチレン 生成での結果とほほ同一の傾向が見られた。

これらのことから, 根部処理でも主に DMPAが
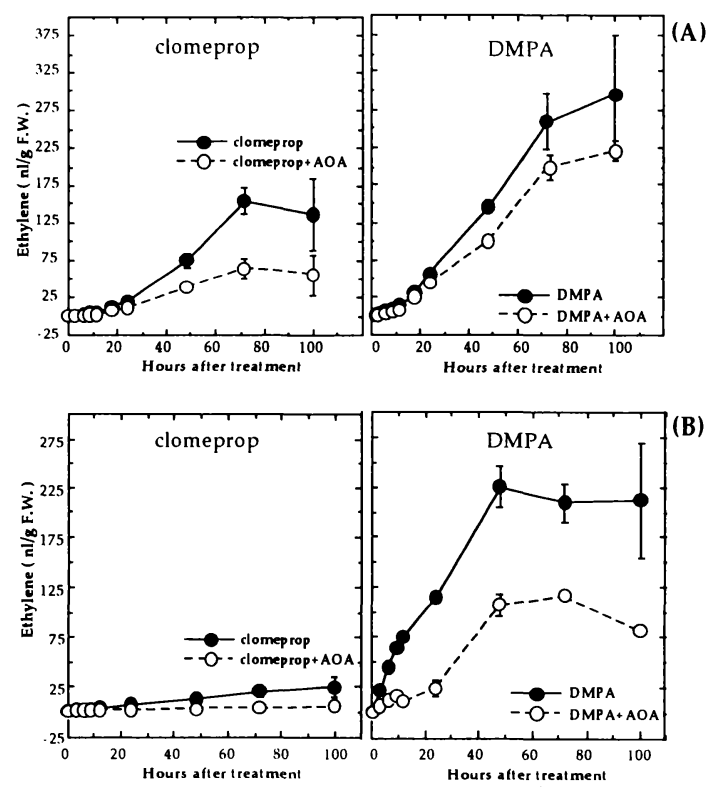

Fig. 3. Ethylene evolution from clomeprop-or DMPA-treated radish seedlings.

(A): shoot application, (B): root application Radish shoots were pretreated with $\mathrm{AOA}$ and then treated with clomeprop or DMPA.

Data represent means \pm SE.
ACC synthase 活性を増大させ, その結果, 植物体内 にエチレンが蓄積することで形態異常を引き起こし ているものと推察された。上記の結果と先行研究等 から, 茎葉と根部処理間で異なる形態異常の程度の 差は, 茎葉, 根部でのクロメプロップと DMPA の吸 収, 移行, 代謝の差により生じた, 茎葉部中の DMPA 量の差が大きく関与しているものと推察された。そ して, その茎葉部中の DMPA 量の差がエチレン生合 成の量的, 時間的差を生み, その結果として形態異 常の程度差を引き起こしている可能性が示唆された。

\section{4. クロメプロップ, DMPA 処理後の幼根から の電解質漏出へのエチレンの関与7)}

クロメプロップ根部処理後の傷害の一つに電解質 の漏出がある。植物ホルモンとしてのエチレンの生 理作用研究においては, エチレンが膜の透過性を増 大させること等が報告されているが, ホルモン型除 草剤処理から電解質漏出までのメカニズムに関して の研究は, 現在までに殆ど行われていない。ここで は, 特にクロメプロップ処理後の電解質漏出におけ るエチレンの関与について検討し, 以下の結果を得 た。

ダイコン幼植物に,クロメプロップまたは DMPA を根部処理すると, 幼根から電解質の漏出が確認さ れた。そして,クロメプロップまたは DMPA 処理後 にエチレン作用の阻害荗である NBD ゃ $\mathrm{PPOH}$ （cis -propenylphosphonic acid）を処理することで，そ の漏出は抑えられた(Fig. 4)。また, DMPAによる 側根の発生阻害も NBD P PPOH によって抑えられ た。さらに,クロメプロップまたは DMPA 処理直後 から，エチレン放出量の顕著な増大が確認された。 そして, エバンス・ブルー染色の結果, DMPA 処理 後の細胞は12時間以降に青色に染まり始めたことか ら, 処理直後から 12 時間以内に引き起こされる電解 質漏出は細胞死によって引き起こされたものではな いことが推察された。

これらのことより, DMPA が ACC synthase を誘 導することによって蓄積するエチレンがクロメプロ ップ, あるいは DMPA 処理後に引き起こされる電解 質漏出に関与しており, 根の細胞膜の完全性が失わ れた結果として側根の生育が阻害されている可能性 が示唆された。 


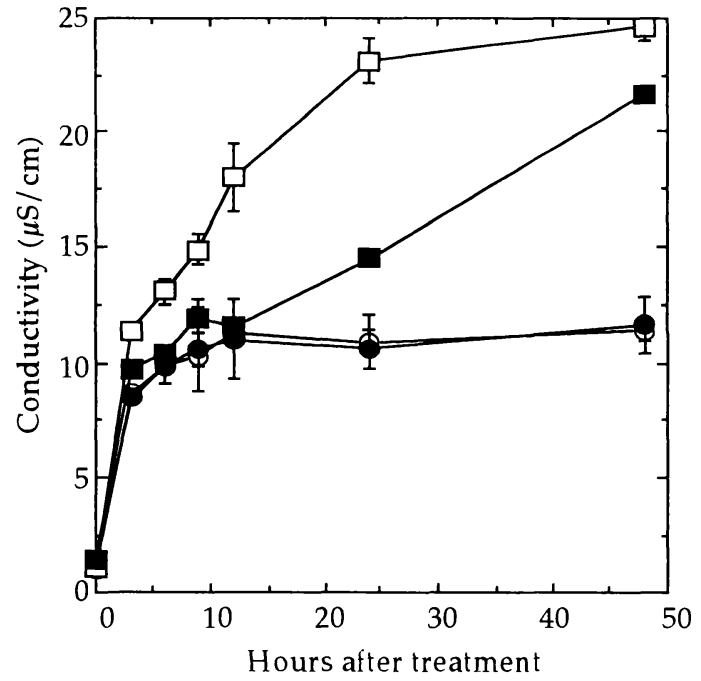

Fig. 4. Effect of PPOH on electrolyte leakage from DMPA-treated radish roots.

Radish roots were soaked with DMPA and then treated with $\mathrm{PPOH}$.

Data represent means \pm SE.

Symbol: $\bigcirc$; control, $\square$; DMPA, O; PPOH, $\square$; $\mathrm{DMPA}+\mathrm{PPOH}$

\section{5. クロメプロップ, DMPA 処理後の幼根から の電解質漏出への活性酸素の関与 ${ }^{8)}$}

上記4.で DMPA 処理後の電解質漏出におけるエチ レンの関与が示唆されたが, 近年, エチレンと活性 酸素との関連についての報告もあることから，ここ では, まず DMPA 処理後の電解質漏出における活性 酸素の関与について調べ，さらに，それに関与する 活性酸素分子種の特定とエチレンとの関りについて 検討した。

ダイコン幼植物にクロメプロップ,DMPA を根部 処理すると, 処理直後から, 根部からの電解質漏出 が確認されたが，その電解質漏出は，フリーラジカ ルの消去剤 (tiron, ascorbate), ${ }^{1} \mathrm{O}_{2}$ の消去剤 (Lhistidine, dabco), • OH の消去鼡 (formate) を前 処理することで軽隇した。そして, それは特に ${ }^{1} \mathrm{O}_{2}$ の 消去剤の前処理で顕著に現れた。また，クロメプロ ップ, DMPA 処理後の電解質漏出に伴う側根の発生 阻害作用もフリーラジカルの消去剤, ${ }^{1} \mathrm{O}^{2}$ の消去剤の 前処理により軽減された。次に, フリーラジカルの

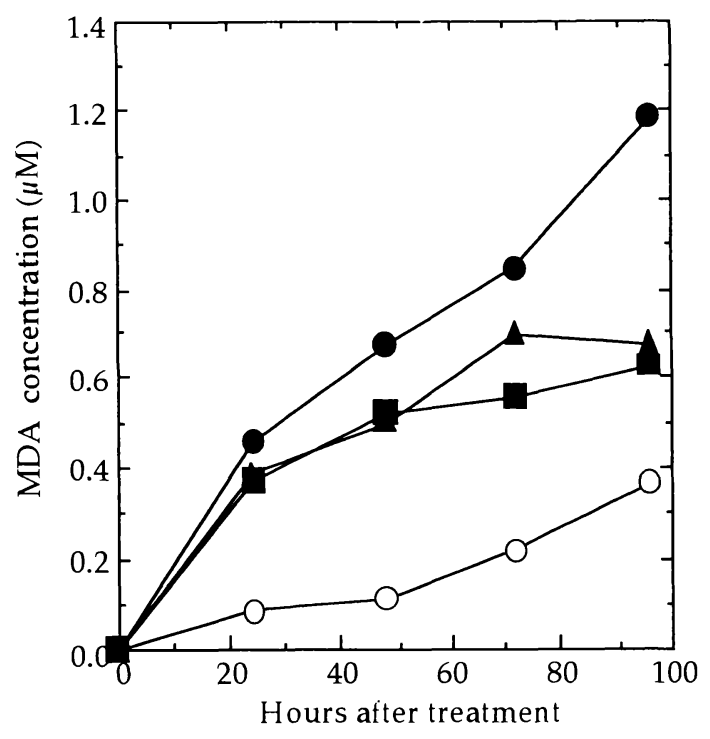

Fig. 5. Effect of dabco or tiron on MDA release from radish roots treated with DMPA.

Symbol: $\bigcirc$; control, 0 ; DMPA, $\mathbf{\square}$; Dabco + DMPA, $\mathbf{\Delta}$; Tiron+DMPA

消去剤, ${ }^{1} \mathrm{O}_{2}$ の消去剤を前処理した後のエチレン発生 量を測定したが, それらの活性酸素消去剤の処理は DMPA 処理後のエチレン生成量に影響を及ほさなか つた。また, チオバルビツール酸法により過酸化脂 質の測定を行った結果, フリーラジカルの消去剈や1 $\mathrm{O}_{2}$ の消去剤の前処理により DMPA 処理後の過酸化 脂質量の減少が認められた（Fig. 5)。

これらの結果より,クロメプロップや DMPA 処理 後におこる電解質漏出には, エチレン以外の要因と して活性酸素 $\left(\right.$ 特に $\left.^{1} \mathrm{O}_{2}\right)$ による膜脂質の過酸化が関 与している可能性があることが示唆された。そして その活性酸素はエチレン生成量を増大させることに よって二次的に電解質漏出を引き起こしているので はなく, 膜の過酸化に直接的に作用している可能性 があるものと推察された。

\section{6. まとめ}

以上, 得られたすべての実験結果から, 現時点で 考えられるクロメプロップの作用機構についてまと めると次のようになる (Fig. 6)。クロメプロップは 植物体内に吸収された後に, 特に茎葉部でアリルア シルアミダーゼによって加水分解を受け, DMPA と 


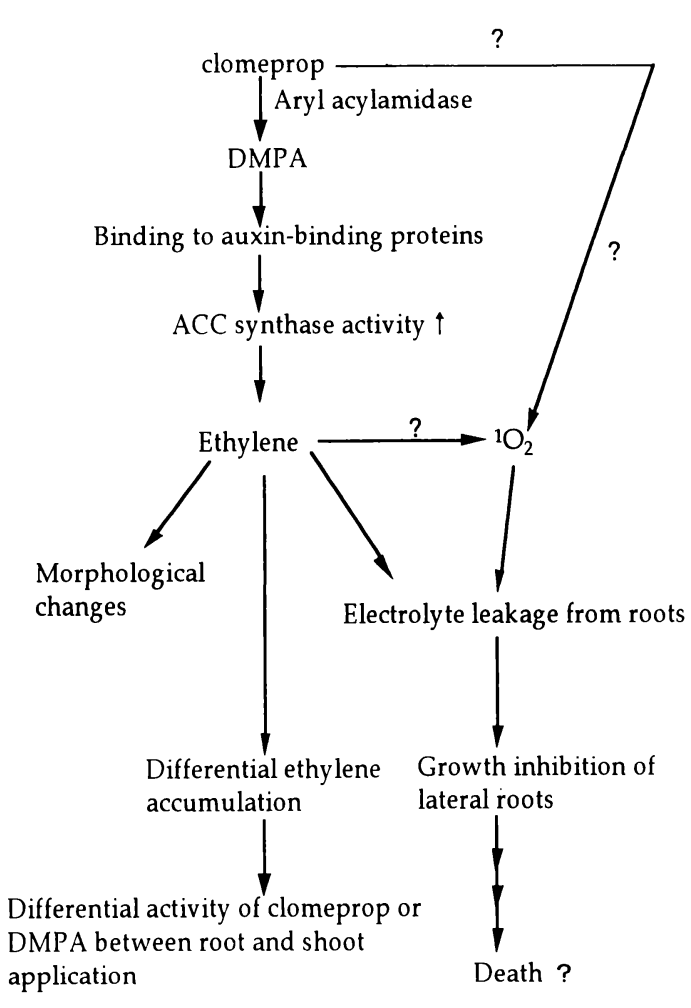

Fig. 6. Proposed mechanism of herbicidal action of clomeprop in susceptible plants.

なる。DMPA は植物体内でオーキシンとして振る舞 い, オーキシン結合蛋白質に結合し, オーキシン活 性を有するようになる。そしてDMPA は ACC synthase 活性を増大させることにより，エチレンを 大量に生成させ, 葉柄間角度の増大, 葉のカーリン グ, 伸長阻害といった形態異常を引き起こす。エチ レンはその他に, 根部での電解質漏出を引き起こし, その膜の完全性を失わせる結果として側根の発生阻 害を起こしている可能性がある。このような DMPA の作用が, クロメプロップ処理から植物体枯死に至 るメカニズムに, 深く関与している可能性が高いも のと思われる。また, クロメプロップ処理による電 解質漏出にはエチレンの他に ${ }^{1} \mathrm{O}_{2}$ が関与していること が示唆されたが, この 2 者間の関わりについては今 後, さらに検討しなければならないと考えている。 また, エチレン作用の生化学的な機構やホルモン型 除草剤による他の生理作用との関連についても, 今 後さらに詳しく追究する必要があろう。
また, クロメプロップは生理生化学的に選択性を 有する除草剤であるが, クロメプロップに対して感 受性である植物と抵抗性である植物との差異は, 吸 収, 移行性の差の他に, クロメプロップから DMPA への代謝の差, あるいは3-メチル基の水酸化された 3- $\mathrm{CH}_{2} \mathrm{OH}-\mathrm{DMPA}$ とその glucose 抱合体になる解毒 代謝速度の差, すなわち DMPA の体内存在量の差が 深く関与しているものと推察された。さらに, 本研 究から, クロメプロップの殺草作用にはエチレン生 合成系が密接に関与していることが示されたことか ら，その生合成に関与する酵素 (ACC synthase や ACC oxidase 等) が欠損している場合や生合成産物 に対する感受性が異なる場合も選択性に大きく関っ ているものと推察される。

本研究遂行にあたり, 筑波大学応用生物化学系松 本宏博士, 同臼井健二博士, 同大学名誉教授石塚皓 造博士には, 終始, 瑟切な御指導, 御教示を賜った。 また, 同大学応用生物化学系小林勝一郎博士, 同沈 利星博士, 順天大学校李度鎮博士には常に有益な御 助言を頂いた。ここに, 深甚なる感謝の意を表する。 また, 佐賀大学応用生物科学科穴井豊昭博士には, 㤠切な実験指導をいただき,さらにプローブを御恵 与いただいた。また, 本研究遂行の為に, 三菱油化 株式会社（現 アベンティス クロップサイエンス ジャパン株式会社)より, クロメプロップと DMPA を御提供いただいた。さらに協和発酵工業株式会社 からは, $\mathrm{PPOH}$ を御提供いただいた。心より感謝申 し上げる。

\section{発表論文および引用文献}

1) Grossmann, K. and J. Kwiatkowski. 1993. Selective induction of ethylene and cyanide biosynthesis appears to be involved in the selectivity of the herbicide quinclorac between rice and barnyard grass. J. Plant Physiol. 142, 457-466.

2 ) 石塚皓造．1986、MY-15の稲における代謝運命試験 報告書. pp.1-25.

3) Peniuk, M. G., M. L. Romano and J. C. Hall. 1994. Physiological investigations into the resistance of a wild mustard (Sinapis arvensis L.) biotype to auxinic herbicides. Weed Res. 33, 431-440.

4 ) Sunohara, Y., K. Usui, H. Matsumoto, M. Sakoda -Hoshi and K. Ishizuka. 1994. Auxinic activity of 
clomeprop and its hydrolytic metabolite and their binding to maize auxin-binding protein. Weed Res., Japan. 39(4), 256-264.

5 ) Sunohara, Y., K. Usui, H. Matsumoto and K. Kobayashi. 1995. Involvement of ethylene in clomeprop-induced actions in radish seedlings. Weed Res., Japan. 40(2), 95-103.

6 ) Sunohara, Y., K. Usui, H. Matsumoto and K. Ishizuka. 1996. Mechanism of hormonal actions induced by root-applied clomeprop in radish seedlings. Weed Res., Japan. 41 (2), 84-89.

7 ) Sunohara, Y., H. Matsumoto, K. Usui and K. Ishizuka. 1996. Ethylene action inhibitors suppressed clomeprop metabolite [2-(2,4-dichloro- $m$ tolyloxy) propionic acid]-induced electrolyte leakage from radish roots. Weed Res., Japan. 41
(3), 234-240.

8 ) Sunohara, Y., H. Matsumoto and K. Usui. 1997. Possible involvement of active oxygen in clomeprop hydrolytic metabolite-induced electrolyte leakage from radish roots. J. Weed. Sci. Tech. 42 (4), 379-385.

9 ) Suwunnamek, U., C. Wongwattana and K. Ishizuka. 1990. Hormonal activity of clomeprop in radish seedlings. Weed Res., Japan. 35, 129-136.

10) Wongwattana, C. and K. Ishizuka. 1988. Metabolism of clomeprop in plant seedlings. Weed Res., Japan. 33, 200-208.

11) Wongwattana, C., U. Suwunnamek and K. Ishizuka. 1990. Hormonal activity and metabolism of herbicide clomeprop as affected by carbamate insecticide NAC. Weed Res., Japan. 35, 169-174. 